\title{
Joseph ben Samuel Șarfati's «Tratado de Melibea y Calisto»: A Sephardic Jew's Reading of the Celestina in Light of the Medieval Judeo-Spanish Go-between Tradition
}

\author{
Michelle M. HAMILTON \\ University of California, Irvine
}

Shortly after La Celestina appeared in Spain, an Italian author, physician and nobleman, Joseph ben Samuel Șarfati (d. 1527), a Sephardic Jew, rendered the work into Hebrew. ${ }^{1}$ This Hebrew version of La Celestina has not survived, but the introductory poem by Sarfati has survived, and it was edited and published by Moshe David Cassuto in 1935 and is available today in both Spanish and English translations. ${ }^{2}$ Sarfati's introductory poem is

\footnotetext{
1 As Guillermo SERÉS points out, the first version of La Celestina, the Comedia, was published in Burgos, between 1499-1502, in Toledo in 1500, and in Sevi1la in 1501; versions of the Tragicomedia, with the additional acts and interpolations, appeared in castellano in 1507 and 1514: «Prólogo,» in Fernando DE ROJAS, La Celestina. Tragicomedia de Calisto y Melibea, eds. F. J. LOBERA, G. SERÉs, P. DíAZ-MAS, D. MotA, I. RuIZ ARZÁlluZ and F. RiCo (Barcelona 2000) pp. 1xxiii-lxxxi. The first Italian version of the Tragicomedia was published in Rome in 1506 , and D. W. MCPHEETERS dates the year given by Sarfati, 438, as 1507 or 1508 A.D. («Una traducción hebrea de La Celestina en el siglo XVI,» in Homenaje a Rodríguez-Moñino. Estudios de erudición que le ofrecen sus amigos o discípulos hispanistas norteamericanos [Madrid 1966] vol. I, p. 403).

2 M. D. CAssuto, «Miširei Yosef ben Smuel Șarfati: Hakomedia Harișona Be'ivrit» [Hebrew], in Jewish Studies in Memory of George A. Kohut. 1874-1933, eds. Salo W. BARON and Alexander MARX (New York 1935) pp. 121-128; D. W. MCPheEters, «Una traducción hebrea de La Celestina...,» pp. 399-411; D. CARPENTER, "A Converso Best-Seller: Celestina and her Foreign Offspring,» in Crisis and Creativity in the Sephardic World 1391-1648, ed. Benjamin R. GAMPEL (New York 1997) pp. 267-281.

Sefarad 62 (2002) págs. 329-347

(c) CSIC

ISSN 037-0894
} 
remarkable in that it not only offers us a glimpse of how Rojas' Tragicomedia was interpreted by a contemporary, but also how the Tragicomedia, i.e. La Celestina, fits within the context of medieval Judeo-Spanish literature.

Of the 62 lines of Sarfati's poem, only about 10 contain explicit references to the plot and characters of the La Celestina. The other 50 or so lines -roughly $85 \%$ of the poem- treat in a very general way some themes found in La Celestina, such as the pangs of love, the suffering of lovers and the deception of speech. Yet Sarfati also introduces a series of motifs that seem somewhat alien to La Celestina. These motifs and themes do correspond, however, to those of two earlier medieval Judeo-Spanish works whose central character is an evil, old go-between: Judah Ibn Šabbatay's «Offering of Yehuda» (1208) and Judah al-Harīīìs «Maqāma of Marriage,» the latter being one of fifty tales collected in the work entitled Tahkemoni (1216).

Both these go-between tales were very popular in the high Middle Ages and continued to be copied and subsequently printed through the seventeenth century and revived again in the nineteenth century. Over twenty manuscript copies of the «Offering of Yehuda» survive from the fourteenth, fifteenth and sixteenth centuries, including a few from Italy. There is still a manuscript copy housed in Padua and in Turin. There are also two print witnesses surviving from the sixteenth-century -one from Salonika (15951593) and one from Constantina (1548)- suggesting it was quite popular among the Sephardic communities of the Diaspora. ${ }^{3}$ Similarly, the Tahkemoni also survives in dozens of manuscripts, including several in Italy (Parma and Montefiore). Like the «Offering of Yehuda», the Tahkemoni also survives in a sixteenth-century printed edition (Constantinople 1578). ${ }^{4}$ Sarfati, an intellectual and member of the influential elite of sixteenth-century Italy would have had access to, and most probably been aware of, these two early thirteenth-century works.

${ }^{3}$ Matti Huss, Critical Editions of Minhat Yehuda, 'Ezrat Hanašim, and 'Ein Mišpat with Prefaces, Variants, Sources and Annotations [Hebrew], vols. 1-2 (Diss. Hebrew University 1991) p. 190.

${ }^{4}$ Carlos Del VAlle RodRíguez gives a detailed list of print and manuscript editions of the Tahkemoni in the introduction to his Spanish translation, Las asambleas de los sabios (Tahkemoni) (Murcia 1988) pp. 21-22. 
In this paper I look at how Joseph Sarfati interprets La Celestina, i.e. the manner in which he summarizes the work's plot and message, and how he addresses other, less familiar themes and motifs in the same poem. I focus especially on the allegory of the war of lovers, the images of entrapment, the idea that women are but vessels for the angels of death, and the concept of Gentile lust. While these motifs and images do correspond to the general imagery of La Celestina, they reflect in a more detailed manner aspects of the early thirteenth-century Judeo-Spanish works. Moshe David Cassuto and Dwayne Carpenter have pointed out that this imagery corresponds to Biblical and medieval Talmudic material, but this Biblical and Talmudic material had already been incorporated into a well-developed go-between tradition, to which the "Offering of Yehuda» and Tahkemoni belong. ${ }^{5}$ The implication, then, is that Sarfati also believed La Celestina was representative of the motifs and themes espoused in this go-between tradition.

\section{ELEMENTS OF LA CELESTINA MENTIONED IN SSARFATI'S INTRODUCTORY POEM}

In the first lines of his introductory poem, Sarfati calls his reader to the «war of lovers,» to «the fierce rage and dread of maidens:»

1. Hark, friends, to the war of lovers Entrapped in Passion's tempting snare;

2. The discourse, too, as both debate With honeyed words and fables fair;

3. The fierce rage and dread of maidens, In whom reproof and love combine;

4. The dulcet words to charming girls, Which on impassioned lips recline.

5. Behold the arms they wield in their desire, As well the servants' scorn and schemes.

${ }^{5}$ M. D. CASSUTO, «Miširei Yosef ben Sarfati...,» pp. 124-128. D. CARPENTER, «The Sacred in the Profance: Jewish Scriptures and the First Comedy in Hebrew,» in Fernando de Rojas and Celestina: Approaching the Fifth Centenary, eds. Ivy A. CorfiS and Joseph T. SNOw (Madison 1993) pp. 232-235. 
6. Their arms are arms of violence;

Destruction and distress their dreams.

7. They plot to steal their master's name;

Revolt each moment they prepare.

8. And there you'll find the cunning crones, And how they lay their traps e'erwhere;

9. And there the words maidservants speak, Aflame in lovers' hearts to light. ${ }^{6}$

These maidens, with their conflicted natures, recall Melibea, whose vehement reproof of Celestina's approaches on Calisto's behalf belie the intense love she feels for him.

In Sarfati's poem Calisto is not mentioned by name, designated simply as one of Melibea's «friends» mentioned in line 45: «Young lovers, all, observe the case of Melibea and her friends.» ${ }^{7}$ Calisto's agency, his deceptive use of the rhetoric of courtly love to woo Melibea, is forgotten. Sarfati mentions only his dulcet words that recline on impassioned lips (line 4 above). Sarfati underscores the misogynist aspect of La Celestina, backing it up with a series of misogynist images from the Judeo-Spanish go-between tradition, as discussed in the next section. The scheming servants described in lines 5-7 who plot to undermine their master's honor clearly describes Sempronio and Pármeno, and, in the cunning crone laying traps everywhere we have Sarfati's reference to the old bawd Celestina. The fiery end the lovers meet («Veer from the path of Gentile lust; above all, flee its fiery end», line 46) ${ }^{8}$ captures the violent deaths of Melibea and Calisto, although the fire imagery does not correspond totally with the lover's falls.

For Sarfati, the characters Celestina, Melibea, Calisto, Sempronio and Pármeno are exemplary. The lovers are but two of seeming legions of similarly deluded people, and Celestina and the servants are only a few examples taken from the multitude of evil and scheming underclasses. Sarfati could simply be depicting them

\footnotetext{
${ }^{6}$ All English translations of Sarfati's poem are from D. CARPENTER, «Converso Best-Seller..., pp. 274-279. Carpenter includes the Hebrew original on pages 279-281. This excerpt is on pages 274-275.

7 Trans. D. CARPENTER, «Converso Best-Seller...,» p. 278.

8 J. SARFATI, trans. D. CARPENTER, «Converso Best-Seller...,» p. 278.
} 
as archetypes of common characters found in fifteenth-century society. However, he may also be singling Celestina and the cast out of a well-established Judeo-Spanish literary go-between tradition, a tradition to which Sarfati may believe they belong, or of which he believes they are a manifestation. The fact that he goes on to allude to motifs and images found in works of that very tradition further supports this idea.

\section{ELEMENTS OF SARFATI'S POEM COMMON TO BOTH LA CELESTINA AND THE JUDEO-SPANISH GO-BETWEEN TRADITION}

\subsection{The character of the old go-between}

Celestina is not the only scheming old go-between in the Spanish literary tradition. In addition to Trotaconventos from the Libro de buen amor, we have two earlier go-between characters that Celestina resembles: Sitnah from al-Harīzī's Tahkemoni and Kozbi from Ibn Šabbatay's «The Offering of Yehuda.»

The protagonist of Al-Harīī's go-between tale, the «Maqāma of Marriage,» encounters an evil old woman, who promises to procure for him a beautiful young maiden:

Lo! I encountered an old hag with evil visage and ugly form. She looked as if Fate had stolen her from the demons to be part of him. And he called her name «Sitnah.» She spoke fair and fell upon her knees, and her mouth was smoother than oil. Honey was upon her tongue but deadly poison was in her throat [...] Now when I heard her speech, my heart was drawn by the smoothness of her words, and I was bound by the cords of her beguilement. ${ }^{9}$

Like Celestina, this woman's speech is characterized as being honey sweet, but deadly like poison. The go-between's cunning is manifest in her speech, which the protagonist compares to cords of beguilement that trap men's wills.

Kozbi, the go-between in «The Offering of Yehuda,» is also portrayed as an evil old hag:

\footnotetext{
${ }^{9}$ Judah Ben Solomon AL-HARİZì, trans. Victor E. REICHERT, The Tahkemoni
} (Jerusalem 1965) vol. 1, pp. 119-120. 
There arose from amongst them a wise woman, a mistress of necromancy and deceit. The rivers could not wash away the sparks of the immensity of her sorceries and whoring. And her name was Kozbi bat Yereša, «Lying, daughter of Inheritance» because she held deceit as an inheritance. ${ }^{10}$

Kozbi's appearance is anticipated by the women of the land, who band together because their husbands and male folk have abandoned them to follow the teachings of the protagonist, Zerah, who claims that women are evil, and having relations with them brings about the downfall of man:

Wherever he went he proclaimed, "Shun Woman as you beware the glittering sword! Seek ease! Find peace! Rid yourselves of jewelry-wearers that your days may be long. To put women to shame is the glory of youth, but shame and scorn will never befall a young man so long as he keeps away from women. The harm of marriage never fades; it destroys the spirit and the flesh alike. When a man marries, his name is covered in darkness. His pain will wax and his glory wane; let him who will, listen, and him who refuses, refrain. Let every husband listen and pay me heed; to make my speech longer there is no need.» ${ }^{11}$

Faced with such an enemy, these women need someone to lead them, someone whose skills of deception and sorcery can help them to get their men back:

But in every town where Zerah's words and doctrine came the women were filled with gall and venom. Hopping with rage they gathered, young and old, widows and girls, to take counsel and to plan action. [...] Their cry and their wail waxed; great was their groaning, terrible their turmoil, and loud their lament: «How shall we requite the man who has brought destruction on

${ }^{10}$ Judah IBN ŠABBATAY, Minhat Yehuda. The translation is mine from lines 302-304 of Matti Huss's Hebrew edition, Critical Editions. No translation of the entire text has been published in English. When possible I have relied on the translations of select passages by Raymond SCHEINDLIN, «The Misogynist,» in Rabbinic Fantasies: Imaginative Narratives from Classical Hebrew Literature, Yale Judaica Series 29, ed. David STERN and Mark J. MIRSKY (New Haven 1990) pp. 275-294; Tova ROSEN, "Sexual Politics in a Medieval Hebrew Marriage Debate,» Exemplaria 12.1 (2000) pp. 157-184; and Ángeles NAVARRO PEIRÓ, Narrativa hispanohebrea (Siglos XII-XV) (Córdoba 1988). All Hebrew texts are from Matti Huss's edition.

${ }^{11}$ IBN ŠABBATAY, trans. R. SCHEINDLIN, «The Misogynist,» p. 277. Lines 271281 in M. Huss, Critical Editions. 
our heads, who has ruined and undone us? [...] The lasses languish, their wombs are waste, their fruit fails, all are virgins not known by man! Zerah has turned us into objects of fear, and now one man has to be shared by seven women! See how great is our trouble! Every virgin is shut up and sealed off: no one enters, and none departs. Why should we lie here in our shame, covered by disgrace? Rouse yourselves; think what to do that the ladies may find lovers! Take charge of this disaster, that the women will court the men. Do not think this matter frivolous or trivial. This man is guilty of a capital crime! By stoning shall he die, and no ransom will get him reprieve, for he has slandered the virgins of Israel. Where are the masters of deceit, experts in intrigue? Where are female treachery and tricks? Their counsels and cunning? Their wiles and wisdom? Their plans and their plots?» ${ }^{12}$

\subsection{Gender war}

This is clearly a gender war, with women banding together to fight Zerah and force men to have relations with them, and while Sarfati's reference to the battle of lovers in the first line of the poem, «Hark, friends, to the war of lovers [...],» does corresponds to elements of Sempronio's misogynist diatribe in Act I of $L a$ Celestina, it also reflects, perhaps more fully, the situation in Ibn Šabbatay's earlier Hebrew composition described above.

Sarfati continues the battle imagery in his poem with descriptions of arms and violence in lines 5 and 6 when he warns of the weapons charming girls use, «Behold the arms they wield in their desire [...] Their arms are arms of violence.» Later in lines 23-24 we discover that the fiercest of warriors is a woman who is stronger than any man:

23. She'll break and then entomb a man; She'll fill with fear a warrior's heart;

24. She'll chasten and bring low the proud; She'll rip a strong man's pride apart. ${ }^{13}$

12 IBN ŠABBATAY, trans. R. SCHEINDLIN, «The Misogynist,»pp. 276-277. Lines 285-299 in M. Huss, Critical Editions.

${ }^{13}$ Trans. D. CARPENTER, «Converso Best-Seller...,» p. 276. 
In sharp contrast to this fierce woman, the character of Calisto in La Celestina is portrayed as indecisive and weak. He is even described as an idiot, «un bobo» in La Celestina comentada. ${ }^{14} \mathrm{He}$ is a less than noble, very urban young man, and does not resemble the proud warriors described by Sarfati as fighting on the battlefield with love/women.

A polemicized view of the relation of the sexes is present in $L a$ Celestina in Sempronio's misogynist diatribe in Act I, in which he advises Calisto against the evils of women, warning him of the way they have consistently proven to be the undoing of men:

Llenos están los libros de sus viles y malos enjemplos, y de las caídas que llevaron los que en algo, como tú, las reputaron. Oye a Salomón do dice que las mujeres y el vino hacen a los hombres renegar [...] ¿quién te contaría sus mentiras, sus trafagos, sus cambios, su liviandad, sus lagramillas, sus alteraciones, sus osadías $[\ldots]$ ? ${ }^{15}$

While Sempronio takes up the misogynist commonplaces of medieval Western literature, he does not portray the relation of the sexes in the military terms of battle, as does Șarfati in his introductory poem.

In Ibn Šabbatay's tale, though, the battle between men and women is explicit, the women are hopping with rage, full of gall and venom and they gather together and formulate a strategy to get their men back and to kill Zerah. Their plan is to be implemented by Kozbi, the old go-between, whom the women choose to exact their vengeance. Kozbi proves to be an able and deadly agent of punishment:

Kozbi prayed, saying: «Lo! Instead of peace, bitterness, I have, bitterness, bitterness. O thou who built the upper chambers in the waters; who gave us private parts: the upper and the lower; who favored men and rejected women; who caused to sprout in man the beard and penis for his fame and glory, and who gave the daughters of Eve passion and the lust of death (the uterus),

${ }^{14}$ Folio 155r, n.4. See P. E. RusSELl, «The Celestina comentada,» in Medieval Hispanic Studies Presented to Rita Hamilton, ed. A. D. DEYERMOND (London 1976) p. 183.

${ }^{15}$ F. DE RojAs, La Celestina, eds. F. J. Lobera et al., p. 39. 
fatten the heart of this man and blind his eyes in order to destroy his transgression.»

She ended her prayer and went out to Zerah's tent. And Zerah, as his pleasantness turned to pain, did not know the Lord had abandoned him. And Kozbi the Cruel stood before him. And Lo! Plague stood before him. ${ }^{16}$

Kozbi, with the women's sanction, is set upon destroying Zerah, and his downfall is described in the physical terms of blindness and plague. Zerah is caught in Kozbi's trap, one sanctioned by the women of the land. He is like the man described by Sarfati in line 20: «The feet of a man in fetters, secured by maids with wrath unchecked.» ${ }^{17}$ We have just witnessed Kozbi and the women's wrath in the passage above.

\subsection{Entrapment}

The man bound by angry women is not the only image of entrapment described by Sarfati. In fact, he uses entrapment extensively in his poem, as for example, in the first line, in which he urges the reader to come see the lovers trapped in Passion's snare. Similar imagery is also found in La Celestina. In Act I Sempronio tells Calisto: "Harto mal es tener la voluntad en un solo lugar cativa,» and later in Act XI, Calisto himself admits to being Melibea's captive: «Melibea es mi vida: yo su cativo, yo su siervo.» ${ }^{18}$ In addition, the servants in the work use hunting imagery to depict the lovers' situation. In Act VIII Sempronio compares Calisto to a blinded partridge trapped by hunters, referring to a hunting technique that involved carrying a vessel containing a light: «[Q]ue con la mucha que en su gesto contemplas, no puedes ver de encandelado, como perdiz con la calderuela.» ${ }^{19}$ In Act XI Pármeno again compares Calisto to a partridge trapped by another hunting technique that seems to have involved a pantomime ox: «El falso boizuelo con su blando cencerrar trae las perdizes a la red; el canto de la serena engaña los simples marineros con su dulzor.» 20

\footnotetext{
${ }^{16}$ IBN ŠABBATAY, Minhat Yehuda, my translation of lines 375-381; M. HuSs, Critical Editions.

${ }^{17}$ Trans. D. CARPENTER, «Converso Best-Seller...,» p. 276.

${ }^{18}$ F. DE Rojas, La Celestina, eds. F. J. LOBERA et al., pp. 36, 233.

${ }^{19}$ F. DE RoJAs, La Celestina, eds. F. J. LOBERA et al., p. 196.

${ }^{20}$ F. DE RojAs, La Celestina, eds. F. J. Lobera et al., pp. 235-236.
} 
The cords, snares and traps to which Sarfati refers, however, also correspond to similar references in the works of al-Harīzi and Ibn Šabbatay, and in fact Sarfati uses some of the same Hebrew phrases as these two Judeo-Spanish authors, offering further support to the idea he is drawing reference not just to La Celestina, but to the Judeo-Spanish go-between tradition, of which La Celestina was but one example. In the first line he refers to the warring lovers as those trapped in Passion's snare, and in describing the old crones, he characterizes them in line 8 as laying traps everywhere: «And there you'll find the cunning crones, and how they lay their traps e'erwhere.» ${ }^{21}$

Go-betweens are not the only ones that lay traps, however, and in lines 49-50 Sarfati chastises his male friends to avoid the traps of maidens:

49. Is it wise, my friends and noble lords,

To be shamed, in maidens' traps to land?

50. Or be like deer without their horns?

Or rams bound by a woman's hand? ${ }^{22}$

In the last line Sarfati goes on to warn them against being emasculated and led by a woman's hand like domesticated animals.

The image of the bound ram is similar to Ibn Šabbatay's description of Zerah after he has fallen in love and enlisted the services of the go-between. Kozbi, in the description of Zerah she gives the women of the land, mixes imagery of the war of lovers and of captivity and the hunt, describing him as women's enemy trapped in her net like a sheep for slaughter:

God has given Zerah our enemy into our hands! I spread my net over him and caught him in my trap. His heart was beguiled by 'Ayala Šeluha; today he falls like a sheep to slaughter. ${ }^{23}$

The entrapment image of the first line of Sarfati's poem, «Passions' tempting snare,» is key in establishing «The Offering of Yehuda» and the Judeo-Spanish tradition as an essential part of the literary context of Sarfati's poem. The thirteenth-century

${ }^{21}$ Trans. D. CARPENTER, «Converso Best-Seller...,» p. 75.

22 Trans. D. CARPENTER, «Converso Best-Seller..., p. 278.

${ }^{23}$ Trans. R. SChEIndlin, «The Misogynist,» p. 283. M. Huss, Critical editions, lines 549-551. 
work, «The Offering of Yehuda» opens with an introductory poem with the same metrical pattern as that of Sarfati's. Not only is the meter the same, but the first line of the «Offering of Yehuda» describes the contents of the work to follow using an entrapment image very similar to that used by Sarfati:

Take a book which will tell the story of a man whose soul was captured in the trap of a woman (bepah 'isâ lekudâ).

In it I mention/record his grief and trouble I put all his hardships in the form of a riddle

Lest a man take a crooked path I'll stand at the crossroads

I've gathered a few intelligent men and a few moral ones I'll raise my voice amongst the gathered audience

In the path of honesty, please gentlemen, does every ascent end in a descent?

So that they don't fall from their good advice my writing will be for them as an exemplum. ${ }^{24}$

This poem makes its didactic nature clear and is explicit in its misogyny -the first line here uses a similar turn of phrase to describe women's traps, bepah 'isâ lekudâ, as that used by Sarfati to describe the snare of Passion, bepah hešak lekudim. Instead of being the trap of Passion (bepah ḩešak) as in Șarfati's poem, Ibn Šabbatay's is the trap of a woman (bepah 'isâ). According to the author, this is an exemplary story of the hardships of a man whose soul is captured by a woman -it is a warning for other intelligent and moral men.

The tale of Zerah is that of a man who, despite all his attempts, does fall into the traps set by women. Zerah and his friends are, in fact, aware of women's tricks and traps, and in their attempts to free themselves, they repeat the same images of entrapment found in the first line, as for example, when they set out to find a land free of women:

This is the land of our enemy, for women live in close proximity to us and we witness their deceits. Let us now chose a place to live lest -a land where no man has been- we fall into their traps and commit great offense. ${ }^{25}$

${ }^{24}$ My translation. M. Huss, Critical editions, lines 1-6.

${ }^{25}$ My translation. M. Huss, Critical editions, lines 253-256. 


\subsection{Azazel and the threat of women}

In an attempt to dissuade Jewish men from being seduced by women and the other cultures they represent, Sarfati reminds his reader that beautiful women only want money, and that within them lies the Devil and the Angel of Death. His advice seems gleaned not from La Celestina, for Melibea is not portrayed as a gold digger, but from the Judeo-Spanish tradition, which portrays greedy, selfish women who demand gold and silver:

29. For naught are songs to win les femmes, And mothers' plaints o'er their lost sons.

30. Gifts of silver and of raiment touch The young belles' hearts; all else they shun.

31. And gold exalts, enchants the swain, And brings forth spikenard from each thorn;

32. Gold is a prince, ennobling men And bringing joy to aged and newborn.

33. Hard hearts will melt with presents rich, And necklaces will calm fierce ire.

34. With these, her lover she'll desire, And kiss, and satisfy in every way.

35. No longer brazen, she'll prepare The food to slake his appetite. ${ }^{26}$

While this does not sound like Melibea, it does sound like the women in Ibn Šabbatay's and al-Harīzī's tales. In fact, in Act XIX, while waiting anxiously for Calisto, Melibea begins to sing, and Calisto, under her window hears her, and answers: "Vencido me tiene el dulzor de tu suave canto.» ${ }^{27}$ Melibea, overjoyed, offers to sing more for his pleasure.

In sharp contrast to the way song cements Melibea and Calisto's love, in the "Offering of Yehuda» Zerah' bride, echoing the sentiment of Sarfati's line 29, refuses to listen to Zerah's song -telling him to shut up with his poetry and to bring on the gold and silver:

${ }^{26}$ Trans. D. CARPENTER, «Converso Best-Seller...,» p. 277.

${ }^{27}$ F. DE RojAs, La Celestina, eds. F. J. LOBERA et al., p. 320. 
Don't talk back to me! Go and fetch me vessels of silver and vessels of gold, dresses and pearls, bracelets and veils, a house and an apartment, a chair and a lamp, [... ] Stop taking up your rhyme! Do not even raise your voice. I have no interest in wisdom or culture [...] Your poems and your lyrics mean nothing to me. ${ }^{28}$

Sarfati goes on to describe these self-interested beauties who bring such suffering to men as angels of Death, host to the Devil, and polluted flesh:

\section{David and Solomon attest}

To you of women's guile and bonds;

40. In them reside angels of death,

As well a devil and his throngs.

41. Each day these [women] with their sorcery carry off the sons Of men; and they destroy all living creatures. ${ }^{29}$

42. Escape their charms; discern their flaws,

Polluted flesh in comely dress. ${ }^{30}$

This passage is the one that most suggests Sarfati had in mind Ibn Šabbatay's «Offering» and al-Harīzī's Tahkemoni, as well as the Celestina, for these descriptions repeat, in some cases verbatim, descriptions in the thirteenth-century Judeo-Spanish works.

The protagonist of al-Harīzì's tale finds, upon ripping off her veil and shift in the wedding chamber, that she is indeed «polluted flesh»:

She resembles in her teeth the teeth of bears

That devour and cut off whatever they find.

Her head is full of boils and her eyes

Rob and destroy the mirth of the heart.

Her stature is like a wall and her legs

Are like two tree stumps of the forest -cut off.

${ }^{28}$ Trans. R. SCHEIndLIN, «The Misogynist,» pp. 285-286. Lines 608-610 in the Hebrew edition of Matti Huss.

${ }^{29}$ For line 41 I have used CARPENTER's literal translation given in note 46, p. 389. Although it breaks the rhyme of the translation, the details are important for this study.

${ }^{30}$ Trans. D. CARPENTER, «Converso Best-Seller...,» p. 277 (except line 41 as noted above). 
And her cheeks are black as coal but her lips

Are the crooked lips of a large-boned ass.

Her figure is the shape of the angel of death

All they that touch her will fall down dead. ${ }^{31}$

The protagonist goes on to compare his wife to Lilith, and asks if she is in league with demons:

Are you fashioned from demons and jinns?

May God send curses upon you!

You are as angels of wrath and destruction towards your brethren.

But to you is the double portion of the first born.

Your shape resembles the goat Azazel

And how did you escape from a land cut off?

As though Fate lusted for Lilith,

And out of love sent you to her as a gift.

Your Creator only created you to be

The helpmate to the Angel of Death!

$[\ldots]$

Your lips are as the lips of bullocks

And your mouth is a grave but your belly is a cave.

And your teeth are like the teeth of a filthy bear,

And in them filth and slime are as a heaped-up dish.

$[\ldots]$

You have a belly like a belly of a bottle

And your shape, like your star, is black.

Your hands are the hands of a hairy ape

And fingers like firebrands in the coking stove,

And the sound of your speech is like an earthquake at midnight, The breath of your mouth is a whirlwind.

And your mouth is a tomb for your eating and drinking-

They turn in your belly to the bitterness of gall. ${ }^{32}$

${ }^{31}$ Trans. V. E. REICHERT, The Tahkemoni, p. 124.

${ }^{32}$ Trans. V. E. REICHERT, The Tahkemoni, pp. 125-126. 
In al-Harīzî̀'s tale the young woman is compared to angels of death two times, first her figure is said to resemble that of the Angel of Death, and in the second she is «as angels of wrath» who kill their brethren, and her figure is that of Azazel, the «goat-God» identified with the Devil. ${ }^{33}$ As in Sarfati's poem here the woman is depicted as in league with demons, šedim. The grotesque description of the woman's body gives a very detailed counterpart to Sarfati's «polluted flesh in comely dress.» Sarfati's poem and now lost rendition of the Celestina into Hebrew seem to have been designed to save young men from these ghastly and terrifying agents of destruction.

\subsection{Gentile lust and the Jewish experience}

Sarfati has undertaken this task not to save just any young men, but for the sake of his Jewish coreligionists. He also makes it clear that the Passion described in such shocking terms in the first line is not the same passion that afflicts everyone, but a very specific kind of lust especially threatening to Jewish men. In line 46 Sarfati warns his readers that the premise for his translation is that it may serve as a warning against «Gentile lust» hešak le'umi. The nature of this passion is, just two lines before described as the worship of women:

44. Fools are they who yield to them [women] And from their worship ne'er depart.

45. Young lovers, all, observe the case Of Melibea and her friends:

46. Veer from the path of Gentile lust; Above all, flee its fiery end. ${ }^{34}$

The phrase in line 46 that Carpenter translates with reservations as Gentile lust is a phrase made of two words, hešak -passion or lust, identified by the Arabs as 'isq, love sickness, a medical disease- and le'ummî, from 'umma -meaning either «the people,» or more specifically «a tribe of Ishmaelites» or of «Median.» ${ }^{35}$

\footnotetext{
${ }^{33}$ Jeffrey Burton Russell, The Devil: Perceptions of Evil from Antiquity to Primitive Christianity (Ithaca 1977) p. 206.

${ }^{34}$ Trans. D. CARPENTER, «Converso Best-Seller...,» p. 278.

${ }^{35}$ Francis Brown, The New Brown-Driver-Briggs-Gaesenius Hebrew and English Lexicon (Peabody, Massachusettes 1979) p. 53.
} 
Sarfati is probably playing with these two meanings, both of which apply in this case. In the broadest sense, the term «lovesickness of the people» refers to the profane love Calisto feels for Melibea, as opposed to a divine love, i.e. the love of God. On the other hand the more specific reading of hešak le'ummî is «the lovesickness of the Ishmaelites or Medianites,» i.e. the love of non-Jews. With the narrower definition Sarfati could send a specific message to his Jewish audience in the Diaspora. The fact that he goes on to state that he has undertaken this Hebrew version of the Celestina for his fellow Jews further underscores the fact that he is identifying the text with a religious discourse:

55. Truly, my tongue has rendered this work

To gladden the poor, the downcast soothe.

56. I translate only the substance, and I place the beauty of my discourse before my fellow Jews. ${ }^{36}$

His intended audience, as stated in the text, and implicitly because of his choice of Hebrew, is the community of Jews. To this community he states that the love Melibea offered (he never names Calisto) is that of the Arabs or Ishmaelites, the non-Jews.

In La Celestina Sempronio does compare Calisto's lovesickness to heresy, asking him if he is a Christian, and Calisto admits he worships Melibea: « ¿Yo? Melibeo só, y a Melibea adoro, y en Melibea creo y a Melibea amo.» ${ }^{37}$ But in Șarfati's poem this lust is described as an Arab, or Medianite lust, and not simply the adoration of the beloved. This portrayal of love as the vehicle of religious assimilation and conversion, i.e. the abandonment of Judaism, is also found in the go-between tradition as it existed in the Hebrew tradition in Iberia in the thirteenth century. I think this tradition informed Rojas, and that we need this tradition as the context for understanding Șarfati's «reading» of La Celestina.

As discussed elsewhere, Kozbi, the go-between in Ibn Šabbatay's tale, takes her name from a Biblical whore, significantly a Medianite woman mentioned in Numbers 13, who leads the Israe-

\footnotetext{
${ }^{36}$ Trans. D. CARPENTER, «Converso Best-Seller...,» p. 278, literal translation of line 56 in note 53 , p. 389.

${ }^{37}$ F. DE RojAs, La Celestina, eds. F. J. LobERA et al., p. 34.
} 
lites away from Judaism and to the worship of idols. ${ }^{38}$ The figure Kozbi became identified with the Arabic philosophical tradition in medieval Iberia, and Jewish scholars who studied secular philosophy were identified with those Biblical Israelites who deserted their faith. ${ }^{39}$ In Ibn Šabbatay's tale the young woman that Kozbi uses to seduce the protagonist is also identified with Arab singing slave girls, who had, in fact, been the source of tension in the Iberian Jewish community. Yom Tov Assis has shown that Jewish noblemen had an affinity for these female Arab slaves and not only fathered many children by them, but also neglected their wives because of them. ${ }^{40}$ Such relationships between Jews and non-Jews led the community to feel that such Gentile slaves had become a threat to Judaism: "[I]n the Hebrew Bible concubinage with one's slave girl was legal as it was in Islam. Only in post-biblical times, when concubinage with foreign women menaced the very character of Jewish religion, did opposition to it become extreme.» ${ }^{41}$ This debate and association of Gentile, Arabic lust with religious and cultural assimilation would have been an integral part of Joseph Șarfati's formation as a Sephardic Jew.

We have a similar situation in al-Harīzī's Tahkemoni, in which al-Harizi himself informs us that the work is designed to restore the Hebrew tradition to the Jews of Iberia and the Diaspora, who had long neglected it in favor of Arabic language and culture, which he portrays as a seductive whore. More than Calisto's heresy, the Judeo-Spanish go-between tradition, in which the theme of Jewish assimilation and the threat of Gentile culture is paramount, served as the context for Sarfati's warning to veer from the path of Gentile lust.

\footnotetext{
${ }^{38}$ For detailed studies of Kozbi see Michelle HAMILTON, «Celestina and the Daughters of Lilith,» Bulletin of Hispanic Studies 75:2 (1998) pp. 153-172; and M. Hamilton, Transformation and Desire: The Go-between in Medieval Iberian Literature (Diss. Univerity of California, Berkeley 2001) pp. 216-226.

${ }^{39}$ For more information on the go-between and Arab philosophy of al-Andalus see Francisco MÁRQUEZ VILlanUEVA, Orígenes y sociología del tema celestines co (Barcelona 1993).

${ }^{40}$ Yom Tov Assis, «Sexual Behaviour in Mediaeval Hispano-Jewish Society,» in Jewish History. Essays in Honour of Chimen Abramsky (London 1988) pp. 37-38.

${ }^{41}$ S. D. Goitein, "The Sexual Mores of the Common People,» in Society and the Sexes in Medieval Islam, Giorgio Levi Della Vida Conferences, ed. Afaf Lutfi AL-SAYYID-MARSOT (Malibu 1979) p. 47.
} 
The fact that Sarfati uses the same motifs and topoi used by Ibn Šabbatay and al-Harīzì in their go-between maqāmas suggests that for Sarfati, La Celestina belonged to this tradition, and as such, further suggests that this Hebrew tradition may have, in part, influenced Rojas himself. All these works are rich in entrapment imagery and misogynist common places. Sarfati's portrayal of the relation of the sexes as an armed battle and his depiction of women as agents of the angel of death and demons, are not, in my opinion, allusions to the plot or characters of the Celestina, but to two other works, the thirteenth-century go-between tales of Ibn Šabbatay and al-Harīizi. In order to understand Sarfati's poem I think we must read it in light of this Judeo-Spanish go-between tradition. I suggest that Sarfati saw the Celestina, or read it, as one of a series of medieval texts dealing with go-betweens, and for Sarfati, a contemporary reader, Rojas' work, like that of Ibn S̆abbatay and al-Harīzī before him, deals with the threat of female, Gentile love to the male, Jewish identity. 


\section{RESUMEN}

El poema que, en el siglo XVI, escribió el judío italiano Samuel Șarfati para introducir su traducción al hebreo de La Celestina, de Fernando de Rojas, hace referencia a unos elementos que no corresponden a los de la obra de F. de Rojas. Éstos incluyen la imagen de la batalla amorosa, la identificación de la mujer con el Ángel de la muerte y con el Diablo (Azazel) y la identificación de la asimilación religiosa con el deseo sexual, caracterizado por Șarfati como «el deseo gentil». En mi opinión, estos elementos encajan mejor con dos relatos de la tradición judeo-española de los siglos XIII-XIV, cuyo protagonista es una alcahueta, el Minhat Yehuda de Judah Ibn Šabbatay y la «Maqāma del matrimonio» de Judah al-Harīzī. En ambas obras hebreas se encuentran semejanzas con el poema de Șarfati en términos de contenido y de forma. Estas semejanzas sugieren que estas obras eran parte del trasfondo histórico-literario en el que se situaba Șarfati (y quizás el mismo F. de Rojas).

PALABRAS ClAVE: Alcahueta, La Celestina, literatura judeo-española, maqāmat, Samuel Sarfati.

\section{SUMMARY}

The introductory poem that the sixteenth-century Italian Jew, Samuel Șarfati, included with his now lost Hebrew translation of Fernando de Rojas' Spanish masterpiece, La Celestina, mentions several elements foreign to Rojas work as we know it today. These include the image of the war of lovers, the description of women as the Angels of Death and as the Devil (Azazel), and the identification of sexual desire and religious assimilation. In my opinion these elements show that Sarfati had in mind two earlier works from the Judeo-Spanish go-between tradition, Minhat Yehuda by Judah Ibn Šabbatay and the «Maqāma of Marriage» by Judah al-Harīzì. In both of these Hebrew works we find images similar to those used by Șarfati, as well as some strikingly similar formal and linguistic characteristics, all of which suggests that these two works were part of the historical-literary background of Șarfati (and, perhaps, Rojas himself).

KeYwORDS: Go-between, La Celestina, Judeo-Spanish Literature, maqāmat, Samuel Sarfati. 